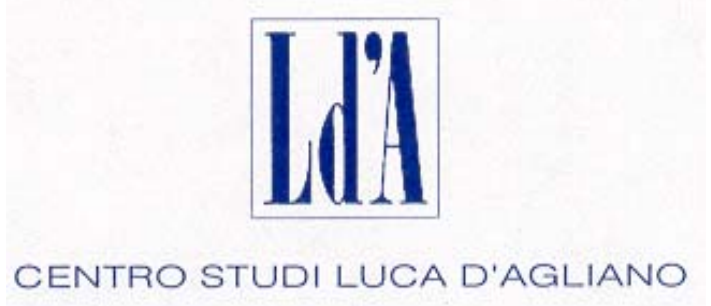

WWW.DAGLIANO.UNIMI.IT

\author{
CENTRO STUDI LUCA D'AGLIANO \\ DEVELOPMENT STUDIES WORKING PAPERS
}

N. 209

March 2006

Migration and Foreign Direct Investment in the Globalization Context: the Case of a Small Open Economy

Artjoms Ivlevs*

* CEDERS, Université de la Mediterranée Aix-Marseille II 


\title{
Migration and Foreign Direct Investment in the Globalization Context: the Case of a Small Open Economy
}

\author{
Artjoms IVLEVS
}

January 2006

\begin{abstract}
:
The main objective of the paper is to establish the link between the exogenous migration shocks and endogenous foreign direct investment flows in a small open economy setting with international capital mobility, immobile labour and a non-traded good. I find that the immigration of the high-skilled individuals and FDI flows are always complements in the quantity sense. The immigration of the low-skilled individuals will cause an outflow (inflow) of capital, if domestic non-traded and imported goods are relatively weak (strong) substitutes in consumption. Besides, I explain the attitudes of native individuals towards high-skilled and low-skilled immigrants.
\end{abstract}

Keywords: international factor mobility, non-traded good, general equilibrium, imperfect import substitution (Armington assumption), direct democracy, EU enlargement.

JEL: F21, F22, J61.

\footnotetext{
* Ph.D. Candidate/ CEDERS, Université de la Méditerranée Aix-Marseille II, 14 avenue Jules Ferry, 13621 Aixen-Provence, France. Tel : +33 (0)4.42.91.48.34, Fax : +33 (0)4.42.91.48.29, e-mail : a.ivlevs@univ-aix.fr . This work is part of my doctoral thesis supervised by Prof. Jaime de Melo.
} 


\section{INTRODUCTION}

Globalization has become a major feature of the modern economic world. The removal of restrictions to international flows of goods and production factors, integration of markets and creation of economic blocks are believed to bring substantial gains to the countries opening their borders, as well as to enhance global welfare. The movement of goods, labour, capital, technology and services in search of better opportunities is constantly growing all over the world, leading to more efficient resource allocation and new patterns of income distribution.

Undoubtedly, increasing liberalization brings about higher interdependence of all channels of integration, creating non-negligible positive and negative externalities. For instance, trade liberalisation is assumed to be a growth-driving factor for the less developed countries. However, the secondary effects may include costly resource reallocation, disappearing of entire industries, and even rising emigration pressures ${ }^{1}$. Migration is not only associated with gains and losses for the host county (in terms of higher growth prospects, resolution of the problems related to social payments and ageing population, transfer of ideas, or illegal immigration), but also has both positive and negative repercussions on sending countries (remittances, brain-drain). Faini (2004) notes that “...Globalisation is not only about the rise in trade, FDI and migration. It is also about the changing linkages among these flows". Therefore, besides separate examination of determinants of trade and factor flows, it is also necessary to explore how different integrated markets interact.

Despite the increased volumes of goods and factors which cross national borders, one must recognise that asymmetries exist in the speed, incentives and policies applied to these movements. In a few last decades, the barriers to international labour movements have become higher than those applied to capital flows and good flows ${ }^{2}{ }^{3}$. In this regard, recent

\footnotetext{
${ }^{1}$ If labour migration entails a monetary cost, some financially constrained would-be migrants are unable to move to the desired destination (especially, in relatively poor countries). Trade liberalisation raises income and relaxes the financial constraint, thereby increasing outward migration. See Lopez and Schiff (1998).

${ }^{2}$ This asymmetry is a characteristic of the present phase of globalization, since it was not manifested in the XIX and early XX centuries (a period characterized by large mobility of both capital and labor) nor in the first twenty five years following the Second World War (a period in which both factors exhibited very little mobility), see United Nations (2004). Faini (2004) calls migration the "grand absentee of the present globalisation period".

${ }^{3}$ The may be several explanations why international labour movements are less liberalised. One obvious reason is that, beyond purely economic considerations, migration flows are associated with additional economic and human costs (nationalism, xenophobia, cultural differences, abuse of social security systems, threats of illegal immigration, intergenerational issues). These non-economic and indirect economic effects contribute to less favourable attitudes to immigration among native voters and as a consequence lead to stricter immigration
} 
enlargement of the European Union provides an interesting example. Economic integration processes between old and new member states, which were initiated in mid-90s, witnessed rapid trade liberalization. Obstacles for FDI flows have also been removed by mutual agreement of both sides, making another step towards integrated single market. On the contrary, the progress toward free movement of labour has been extremely slow, and was determined in potential host countries more by political and social, than economic considerations. Currently, only three of the old member states are open for migrants from the new states ${ }^{4}$, the others introduced 2 to 7 years transition periods. Migration issues continue to be central in the on-going negotiations on Turkey's accession to the EU.

Relatively high restrictions to legal immigration suggest that actual international labour flows are determined by changes in national regulation (such as imposition of immigration quotas), and not solely by wage differential in sending and receiving countries. It is also reasonable to assume that the supply of immigrants is inelastic, implying that the wage differential is always high enough to fill the imposed immigration quotas. On the contrary, less regulated international capital flows are more likely to respond to differences in capital price, thereby leading to capital reward equalisation across borders. Overall, we can consider immigration flows as exogenous and capital flows endogenous.

The objective of this paper is twofold. First, it will attempt to establish the link between the international flows of productive capital and labour taking into account the above-mentioned asymmetry, and thereby will contribute to the literature on the links between migration, trade and FDI flows. Precisely, I will study the response of endogenous capital flows to exogenous migration shocks. The second objective of the paper is to determine attitudes towards immigration when capital is becoming increasingly mobile, both between sectors and across national borders. The resulting attitudes will then be compared to the case where capital is not allowed to move across borders, based on the conclusions of my previous work 'Attitudes towards immigration in a small open economy".

The set-up for studying the relationship between factor flows is a natural extension of the model I developed in Ivlevs (2005), which I accommodate now for internationally mobile

policies. See, for example, Hillman and Weiss (1999) and Schiff (2002) for the role of non-economic factors in international labour migration.

${ }^{4}$ The United Kingdom, Ireland and Sweden. 
capital. I find that inflow of high-skilled immigrants always leads to inward capital flows, suggesting complementary relationship between the two. On the other hand, low-skilled immigration and FDI are substitutes (complements) in the quantity sense, if the elasticity of substitution between domestic non-traded and imported good is lower (higher) than the elasticity of factor substitution in domestic non-traded sector.

The remainder of the paper is structured as follows. Section 2 provides a brief overview of the literature on the links between factor flows. The model is developed in section 3. I turn to the analysis of the endogenous capital response to migration shocks in section 4 . Section 5 focuses on natives' welfare change due to immigration and consecutive FDI flows, and explains attitudes towards immigrants. Conclusions follow in section 6.

\section{RELATED CONTRIBUTIONS}

A substantial amount of economic literature describes the substitutability relationship of trade vis-à-vis factor flows (see, e.g. Faini, de Melo and Zimmermann 1999 for a survey), and only few contributions address the links that exist between different factor flows. This section aims at providing a brief overview of main findings explaining the linkages between capital and migration flows.

Wong (1986), (2004) surveys different concepts of substitutability between factor flows. He identifies four senses in which factor flows can be substitutes or complements ${ }^{5}$ : quantitativerelationship (or quantity), price equalization, world-efficiency and national-welfare sense $\mathrm{e}^{6}$. These concepts are closely related but they need not be identical. In my paper, I will study whether an exogenous inflow of labour will result in positive or negative capital flows for the

\footnotetext{
${ }^{5}$ Wong (1986) focuses on the substitutability concepts between trade and factor flows (Appendix A, p.41), Wong (2004) applies the same concepts when analysing the relationship between factor flows (labour and capital).

${ }^{6}$ In the quantitative-relationship (or quantity) sense, labour and capital flows are substitutes (complements), if the a small exogenous increase in the volume of flow of one of them leads to a decrease (an increase) in the volume of flow of the other. The factors are said to be substitutes (complements) in the price equalization sense, if each of them is sufficient (both are necessary) to give efficient allocation of resources in the world and to ensure the equalization of factor prices in host and source countries. In the world-efficiency sense, substitutes (complements) refer to the case where either (both) labour or capital mobility is sufficient to establish efficiency in world production, and hence maximise potential world welfare. Finally, in the national welfare sense, factors are substitutes (complements) if either of them are is sufficient to bring maximum welfare to the domestic economy, and complements if both of them are required.
} 
immigration receiving country, thereby combining Wong's quantity and national-welfare notions of substitution. I will say that FDI and migration are complements (substitutes) if a particular country experiences inflows of both factors (an inflow of one factor causes an outflow of the other).

The simplest case to assess substitutability between labour and capital movements is to consider a two country world where only one good is produced with labour and capital ${ }^{7}$ (Wong, 2004). If relative factor endowments are different between two countries, so are factor price ratios. Factor market liberalisation leads to the movement of a factor from a country where it is relatively abundant to a country where it is relatively scarce. As a result, factor prices are equalised across countries. Capital and labour flows in this case are substitutes both in price and quantity sense.

A famous result of Mundell (1957) states that in 2x2x2 Heckscher-Ohlin model trade and factor flows are substitutes in the price and quantity sense. Under free trade and production diversification, factor prices are equalized across countries, leading zero incentives to factor movements. Thus, neither capital, nor labour movements are necessary to increase the efficiency of resource allocation. However, if under free trade a country experiences an exogenous inflow of one production factor, then factor prices stay constant and there is no additional motivation for the other factor to move. Therefore, labour and capital in such a framework are neither complements, nor substitutes ${ }^{8}$.

Baldwin and Venables (1994) study the interaction between different types of factor mobility in the European Eastern enlargement context. They assume that human capital and physical capital are complements, therefore the rate at which foreign capital flows into new member states affects high-skilled labourers' wage. Since current and expected wage differentials influence the decision of the high-skilled to emigrate, the inflow of capital will affect the long-run level of human capital. The changes in the stock of high-skilled workers in turn affect the return on foreign investment, meaning that there is circular relationship between high-skilled labour and capital flows, and that long-run factor endowments in the new

\footnotetext{
${ }^{7}$ The limitation of such a framework is the absence of trade in goods.

${ }^{8}$ More interesting conclusions follow if one switches from the long-run to medium- and short-run perspective. In this case, some factors are immobile across industries, and factor price equalization theorem does not hold. Then an exogenous inflow of one factor induces the movement of the other.
} 
member states are not predetermined. Baldwin and Venables introduce an externality linking the cost of absorbing foreign capital to the stock of skilled labour in the country, and establish that two expectations transition paths are possible: "vicious", associated with high levels of skilled labour emigration and low levels of foreign capital inflow, and "virtuous" involving little emigration, substantial inflows of foreign capital and technology, and rising wages in the Eastern European states.

Davis and Weinstein (2002) use the example of the United States and argue that high-skilled labour, low-skilled labour and capital simultaneously seek to enter the US economy because of the technological superiority with respect to the rest of the world. Factor flows in such a case are complementary in the quantity sense.

One of the differences of the present paper vis-à-vis the mentioned contributions is the assumption of asymmetry in labour and capital flows. I assume that capital can move freely across borders implying capital price equalization in the world, whereas movements of labour are subject to national immigration policy. The production side of the economy takes RicardoViner characteristics: capital (mobile factor) can circulate freely across sectors in the domestic economy, and labour is sector specific. I introduce a sector producing a non-traded good and assume that it employs mobile capital and low-skilled labour. A second sector produces exported good and by assumption is specific in high-skilled labour. Thus, my first objective is to find how the exogenous inflows of sector specific factors (either low-skilled or high-skilled labour) would change the flows of mobile factor (capital). In the second part of the paper, I discuss whether native individuals would favour such inflows of foreign labour, based on the analysis of individual welfare changes. 


\section{THE MODEL}

In this section I lay out the model and establish the link between the exogenous migration and endogenous capital flows, using a general equilibrium framework ${ }^{9}$. Sub-section 3.1. develops supply side of the model, and provides an answer in which direction the FDI would go after the inflow of either low-skilled, or high-skilled foreign workers, if the prices of both goods are fixed at the international market. Then in sub-section 3.2. I introduce a domestic nontraded good, which is an imperfect substitute for the imported good. In the last sub-section I show the initial equilibrium.

\subsection{SUPPLY SIDE}

In this sub-section, I describe briefly the production structure of the economy, and establish the formal link between factor prices and factor supplies, following the analysis of $3 \times 2$ specific-factor model in Jones (1971). Before introducing the consumption side with the nontraded good, I show how capital would respond to migration chocks if both consumption goods were tradable.

Let's consider a classic Ricardo-Viner two-sector economy producing two goods with three factors of production. I denote the two goods and the corresponding industries by $\mathrm{D}$ and $\mathrm{E}^{10}$. Each industry uses one kind of labour, $V_{D}$ and $V_{E}$, and some amount of capital, $V_{N D}$ and $V_{N E}$. I let the low-skilled (high-skilled) labour be specific to D (E) industry. The production function in each sector exhibits constant returns to scale, and the marginal product of capital is diminishing. $a_{D D}\left(a_{E E}\right)$ is the amount specific factor $V_{D}\left(V_{E}\right)$ necessary to produce one unit of good D (E). The amount of the mobile factor necessary to produce one unit of the domestic (export) good is equal to $a_{N D}\left(a_{N E}\right)$.

Under the assumption of full employment of factors the following conditions hold:

$a_{D D} D=V_{D}$

\footnotetext{
${ }^{9}$ This extended version of the model can be found in Ivlevs (2005). However, there capital is not mobile internationally.

${ }^{10} \mathrm{D}$ (E) willl correspond to the domestic non-traded (exported) good in a general equilibrium analysis.
} 
$a_{E E} E=V_{E}$

$a_{N D} D+a_{N E} E=V_{N}$

Following Jones $(1971,1975)$, equations linking the changes in goods and factor prices are ${ }^{11}$ :

$\theta_{D D} \hat{R}_{D}+\theta_{N D} \hat{R}_{N}=\hat{p}_{D}$

$\theta_{E E} \hat{R}_{E}+\theta_{N E} \hat{R}_{N}=\hat{p}_{E}$,

where $R_{N}, R_{D}, R_{E}$ stand for the rewards to the mobile and specific factors, respectively; $p_{D}$ and $p_{E}$ are goods' prices; $\theta_{i j}, i=D, E, N, j=D, E$, is factor's $i$ share in total income generated in sector $j$, and '^' over a variable denotes the relative change in that variable.

Let $\sigma_{D}$ be the elasticity of substitution between factors in industry $\mathrm{D}$, relating the change in the $\frac{a_{N D}}{a_{D D}}$ to the change in the factor price ratio (a comparable definition is applied to the sector E):

$$
\sigma_{D}=\frac{\left(\hat{a}_{N D}-\hat{a}_{D D}\right)}{\left(\hat{R}_{D}-\hat{R}_{N}\right)} \quad\left(\sigma_{E}=\frac{\left(\hat{a}_{N E}-\hat{a}_{E E}\right)}{\left(\hat{R}_{E}-\hat{R}_{N}\right)}\right)
$$

Using equations (1)-(6) one obtains formal solutions for the effects on factor returns of changes in commodity prices and factor endowments (change equations):

$$
\begin{aligned}
& \hat{R}_{D}=\left[\beta_{D}+\frac{1}{\theta_{D D}} \beta_{E}\right] \hat{p}_{D}-\frac{\theta_{N D}}{\theta_{D D}} \beta_{E} \hat{p}_{E}+\frac{1 \theta_{N D}}{\Delta \theta_{D D}}\left(\hat{V}_{N}-\lambda_{N D} \hat{V}_{D}-\lambda_{N E} \hat{V}_{E}\right) \\
& \hat{R}_{E}=\left[\beta_{E}+\frac{1}{\theta_{E E}} \beta_{D}\right] \hat{p}_{E}-\frac{\theta_{N E}}{\theta_{E E}} \beta_{D} \hat{p}_{D}+\frac{1 \theta_{N E}}{\Delta \theta_{E E}}\left(\hat{V}_{N}-\lambda_{N D} \hat{V}_{D}-\lambda_{N E} \hat{V}_{E}\right) \\
& \hat{R}_{N}=\beta_{D} \hat{p}_{D}+\beta_{E} \hat{p}_{E}+\frac{1}{\Delta}\left(\lambda_{N D} \hat{V}_{D}+\lambda_{N E} \hat{V}_{E}-\hat{V}_{N}\right)
\end{aligned}
$$

\footnotetext{
${ }^{11}$ See Ivlevs (2005) for the derivation of all equations.
} 
where $\lambda_{N j}$ is the fraction of the mobile factor absorbed by the $\mathrm{j}$-th industry, $j=D, E$;

$$
\Delta=\sum_{i=D, E} \lambda_{N i} \frac{\sigma_{i}}{\theta_{i i}} ; \quad \beta_{i, i=D, E}=\frac{\lambda_{N i} \frac{\sigma_{i}}{\theta_{i i}}}{\sum_{i} \lambda_{N i} \frac{\sigma_{i}}{\theta_{i i}}} ; \quad \sum_{i=D, E} \beta_{i}=1
$$

The assumption of perfect international capital mobility implies that any downward (upward) pressure on the price of capital would cause a negative (positive) flow of capital. In the economy where capital is mobile both internationally and between industries, exogenous increases in both types of labour raise the price of capital due to higher marginal product of the latter. Assuming that both goods are tradable $\left(\hat{p}_{D}=\hat{p}_{E}=0\right)$, substitution of $\hat{R}_{N}$ for 0 in equation (9) yields positive values for the change in the amount of capital due to foreign labour inflow $\left(\frac{\hat{V}_{N}}{\hat{V}_{j}}=\lambda_{j N}, j=D, E\right)$. In this case, capital "follows" labour.

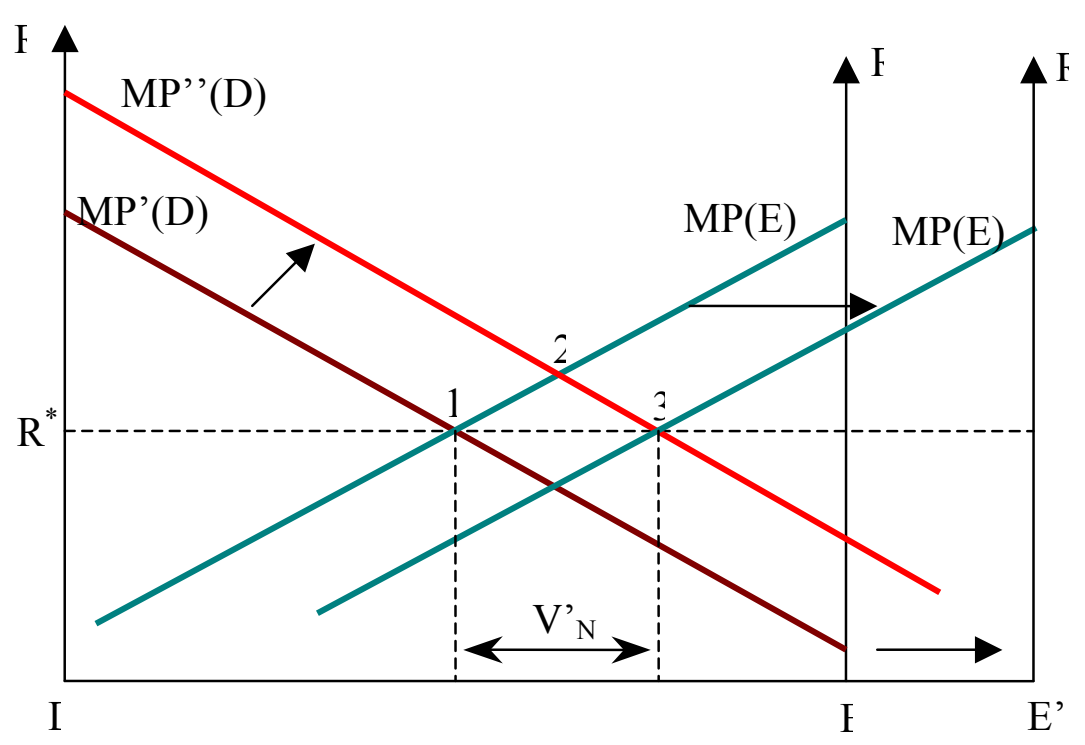

Figure 1. The inflow of low-skilled labour and a consequent rise in FDI, when goods prices stay constant.

Graphically, an increase in supply of either type of labour (for example, the inflow of lowskilled foreigners is shown in figure 1) shifts the marginal product of capital schedule in the respective sector upwards (from MP' to MP' '). The domestic return to capital raises instantaneously (point 2), which attracts foreign capital to the country. The total amount of 
capital in the economy increases, pushing down the price of capital until its world equilibrium level $R^{*}$ is reached (point 3). On the graph, this corresponds to the leftward shift of the left vertical axis. The distance $\mathrm{EE}^{\prime}$ is equivalent to $\mathrm{V}^{\prime}{ }_{\mathrm{N}}$ and represents the inflow of foreign capital.

Note that with constant consumption prices the rewards to specific factors, domestic lowskilled and high-skilled labour, are not affected by immigration (equations (4) and (5)). Thus, the natives, independently of their factor ownership, would be indifferent to both types of immigrants if capital is mobile internationally and the goods produced in the economy are tradable.

The equation that expresses production volumes changes as a function of goods prices and factor supplies is given by:

$$
(\hat{D}-\hat{E})=\Omega\left(\hat{p}_{D}-\hat{p}_{E}\right)+\left(\hat{V}_{D}-\hat{V}_{E}\right)+\frac{1}{\Delta}\left(\frac{\theta_{N D} \sigma_{D}}{\theta_{D D}}-\frac{\theta_{N E} \sigma_{E}}{\theta_{E E}}\right)\left(\hat{V}_{N}-\lambda_{N D} \hat{V}_{D}-\lambda_{N E} \hat{V}_{E}\right)
$$

where $\Omega=\theta_{N D} \frac{\sigma_{D}}{\theta_{D D}} \beta_{E}+\theta_{N E} \frac{\sigma_{E}}{\theta_{E E}} \beta_{D}$.

\subsection{DEMAND SIDE.}

The demand side of the model is based on the Armington assumption, under which imperfect substitution exists between two consumption goods: a domestic non-traded good (D) and an imported good (M). The domestic non-traded good is wholly produced and consumed domestically at a given time period, implying that the non-traded good market is always in equilibrium. The non-traded good is imperfect substitute for the imported good, and the degree (elasticity) of substitution given exogenously by parameter $\sigma$. If $\sigma$ tends to infinity, both consumption goods are perfect substitutes and the (change in) price of the non-traded good does not differ from the (change in) imported good price. At the other extreme, if the elasticity of substitution for imports tends to zero, and the change in imported good price will not be entirely translated into non-traded good price. Formally, the aggregate consumption function (Q) takes a CES form over two goods: 
$Q(M, D, \sigma)=\left[\chi M^{(\sigma-1) / \sigma}+(1-\chi) D^{(\sigma-1) / \sigma}\right]^{\sigma /(\sigma-1)}$

where $\chi$ is a parameter that weights the import good relative to the home good.

Maximisation of (11) subject to the consumers' budget constraint yields:

$\frac{M}{D}=k\left(\frac{p_{D}}{p_{M}}\right)^{\sigma}$

where $k=\left(\frac{\chi}{1-\chi}\right)^{\sigma}$ is a constant and $p_{D}$ and $p_{M}$ are prices paid by domestic consumers for domestic and import good.

\subsection{INITIAL EQUILIBRIUM}

To close the model, a relationship between the goods supplied and demanded in the economy is necessary. As mentioned above, the non-traded good market is always in equilibrium. Concerning traded goods, the assumption is made that all export revenues are used to purchase imports, thus keeping trade balance at zero value. With world prices of exports and imports given by $\pi_{e}$ and $\pi_{m}$, the following equality holds:

$\pi_{M} M=\pi_{E} E$

Choosing the nominal exchange rate as numeraire and assuming the absence of import tariffs and export subsidies, the domestic price for imports and the price at which exports are sold are equal to the respective world prices. 
Given the assumptions about foreign prices and equilibrium in the non-traded good market, the consumption price ratio will be equal to the production price ratio $\left(p_{D} / p_{M}=p_{D} / p_{E}\right)$.

\section{IMMIGRATION, FACTOR PRICES AND CAPITAL FLOWS}

Contrary to standard Ricardo-Viner model, where both goods are tradable, in this model the inflow of foreign labour will have an effect on the price of non-traded good. Moreover, the endogenous response of capital flows to immigration also alters the non-traded good price. Since the change in $p_{D}$ and factor supply changes have a direct influence on the price of capital, the expression linking the change in capital price, factor supply changes and the change in non-traded good price is necessary.

Differentiation of equations (12) and (13) and use of (10) yields a following system (at constant import and export prices):

$$
\left\{\begin{array}{l}
(\hat{D}-\hat{E})=\Omega \hat{p}_{D}+\left(\hat{V}_{D}-\hat{V}_{E}\right)+\frac{1}{\Delta}\left(\frac{\theta_{N D} \sigma_{D}}{\theta_{D D}}-\frac{\theta_{N E} \sigma_{E}}{\theta_{E E}}\right)\left(-\lambda_{N D} \hat{V}_{D}-\lambda_{N E} \hat{V}_{E}+\hat{V}_{N}\right) \\
\hat{M}-\hat{D}=\sigma \hat{p}_{D} \\
\hat{M}-\hat{E}=0
\end{array}\right.
$$

Solution of (14) provides an expression for the change in the non-traded good price as a function of changes in production factor supplies:

$$
\hat{p}_{D}=-\frac{1}{(\sigma+\Omega)}\left(\alpha_{D} \hat{V}_{D}+\alpha_{E} \hat{V}_{E}+\alpha_{N} \hat{V}_{N}\right),
$$


where $\quad \alpha_{D}=1-\lambda_{N D} \frac{1}{\Delta}\left(\frac{\theta_{N D} \sigma_{D}}{\theta_{D D}}-\frac{\theta_{N E} \sigma_{E}}{\theta_{E E}}\right), \quad \alpha_{E}=-1-\lambda_{N E} \frac{1}{\Delta}\left(\frac{\theta_{N D} \sigma_{D}}{\theta_{D D}}-\frac{\theta_{N E} \sigma_{E}}{\theta_{E E}}\right)$, $\alpha_{N}=\frac{1}{\Delta}\left(\frac{\theta_{N D} \sigma_{D}}{\theta_{D D}}-\frac{\theta_{N E} \sigma_{E}}{\theta_{E E}}\right)$

It can be proved that coefficient $\alpha_{D}$ is positive, $\alpha_{E}$ is negative, and the sign of $\alpha_{N}$ depends on the distributive shares with which the mobile factor is used in both industries, $\theta_{N i}, i=D, E$, as well as the elasticities of substitution of production in both sectors $\sigma_{i}$, $i=D, E$. Thus, the inflow of the low-skilled foreign labour diminishes the price of the nontraded good, high-skilled immigrants raises it, while the impact of capital inflow on the nontraded good price depends on the production process characteristics, namely, in which sector the largest part of the inflowing FDI will be employed. The higher is degree of substitution between import and non-traded goods, the less impact on non-traded good price will be made by changes in factor supplies. In what follows, the consequences of high-skilled and lowskilled immigration will be discussed separately.

\subsection{HIGH-SKILLED IMMIGRATION}

There are two channels through which the inflow of high-skilled foreign individuals affects the return to capital. First, higher amount of export industry specific factor raises marginal product of capital, and consequently, its price. Second, the expansion of export industry vis-àvis non-traded sector makes non-traded good relatively scarcer and more expensive. This will move the marginal product of capital schedule upwards, leading to an additional rise in capital price. Inserting equation (15) into (9) yields the formal expression for the change in capital price due to high-skilled immigration:

$\hat{R}_{N}=\beta_{D} \hat{p}_{D}+\frac{\lambda_{N E} \hat{V}_{E}}{\Delta}=-\beta_{D} \frac{\alpha_{E} \hat{V}_{E}}{(\sigma+\Omega)}+\frac{\lambda_{N E} \hat{V}_{E}}{\Delta}>0$

Assuming that domestic return to capital was equal to its world equilibrium level prior to immigration, higher capital price after the inflow of high-skilled immigrants must immediately attract foreign capital in order to restore equilibrium. However, the inflowing 
capital does not only decrease its price, but also alters the price of the non-traded good, according to equation (15). The direction of change of non-traded good price can be both positive and negative, depending on production parameters $\theta_{N i}$ and $\sigma_{i}, i=E, D$, thereby also determining the scope of final FDI flow.

To obtain the formal expression for the endogenous capital response due to high-skilled immigration, I use equation (9) to which I substitute equation (15) for non-traded good price. The capital price increase to be offset by capital and non-traded price movements is given by (16.1), which with negative sign enters the RHS of equation (9):

$$
\begin{aligned}
& (-1)\left(-\beta_{D} \frac{\alpha_{E} \hat{V}_{E}}{(\sigma+\Omega)}+\frac{\lambda_{N E} \hat{V}_{E}}{\Delta}\right)=-\beta_{D} \frac{\alpha_{N} \hat{V}_{N}}{(\sigma+\Omega)}-\frac{\hat{V}_{N}}{\Delta} \\
& \hat{V}_{E}\left(\beta_{D} \frac{\alpha_{E}}{(\sigma+\Omega)}-\frac{\lambda_{N E}}{\Delta}\right)=-\hat{V}_{N}\left(\beta_{D} \frac{\alpha_{N}}{(\sigma+\Omega)}+\frac{1}{\Delta}\right) \\
& \frac{\hat{V}_{N}}{\hat{V}_{E}}=\frac{\left(-\beta_{D} \frac{\alpha_{E}}{(\sigma+\Omega)}+\frac{\lambda_{N E}}{\Delta}\right)}{\left(\beta_{D} \frac{\alpha_{N}}{(\sigma+\Omega)}+\frac{1}{\Delta}\right)}
\end{aligned}
$$

The nominator in the RHS of the last equation is positive, given that $\alpha_{E}$ is negative. The proof that also the denominator $\left(\beta_{D} \frac{\alpha_{N}}{(\sigma+\Omega)}+\frac{1}{\Delta}\right)$ is positive is available in appendix. This means that the effect from capital inflow on the reduction of capital price always surpasses the possible opposite effect from non-traded price change (if $\alpha_{N}$ is negative), and FDI will unambiguously grow after the inflow of high-skilled immigrants. Concerning the quantity of the inflowing FDI, the degree is substitution between consumption goods, as well as the sign of $\alpha_{N}$ are crucial. If the non-traded and imported goods are strong (perfect) substitutes $(\sigma \rightarrow \infty)$, the effect of non-traded good price vanishes (whatever the sign of $\alpha_{N}$ ), and FDI increases by $\lambda_{N E}$ per cent due to 1 per cent increase in high-skilled immigration. If $\sigma$ takes some finite value, positive (negative) value of $\alpha_{N}$ implies lower (higher) inflowing FDI volumes; alternatively, if the main beneficiary of capital inflow due to high-skilled 
immigration is export sector (negative $\alpha_{N}$ ) there will be more FDI than if the domestic nontraded sector were to assimilate the major part of the inflowing foreign capital.

I show the effect of high-skilled immigration of FDI flows on figures 2.1. and 2.2. The inflowing high-skilled individuals are immediately assimilated in the export industry, which moves the marginal product of capital curve in export sector upwards (from MP(E) to MP'(E)). The relative scarcity of the non-traded good results in its higher price and an upward movement of MP(D) schedule in domestic non-traded good sector (from MP(D) to MP'(D)). Both effects contribute to the rise in the price of capital from $R^{*}$ to $R^{\prime}$. This corresponds to the movement of equilibrium from point 1 to point 2 in both graphs.

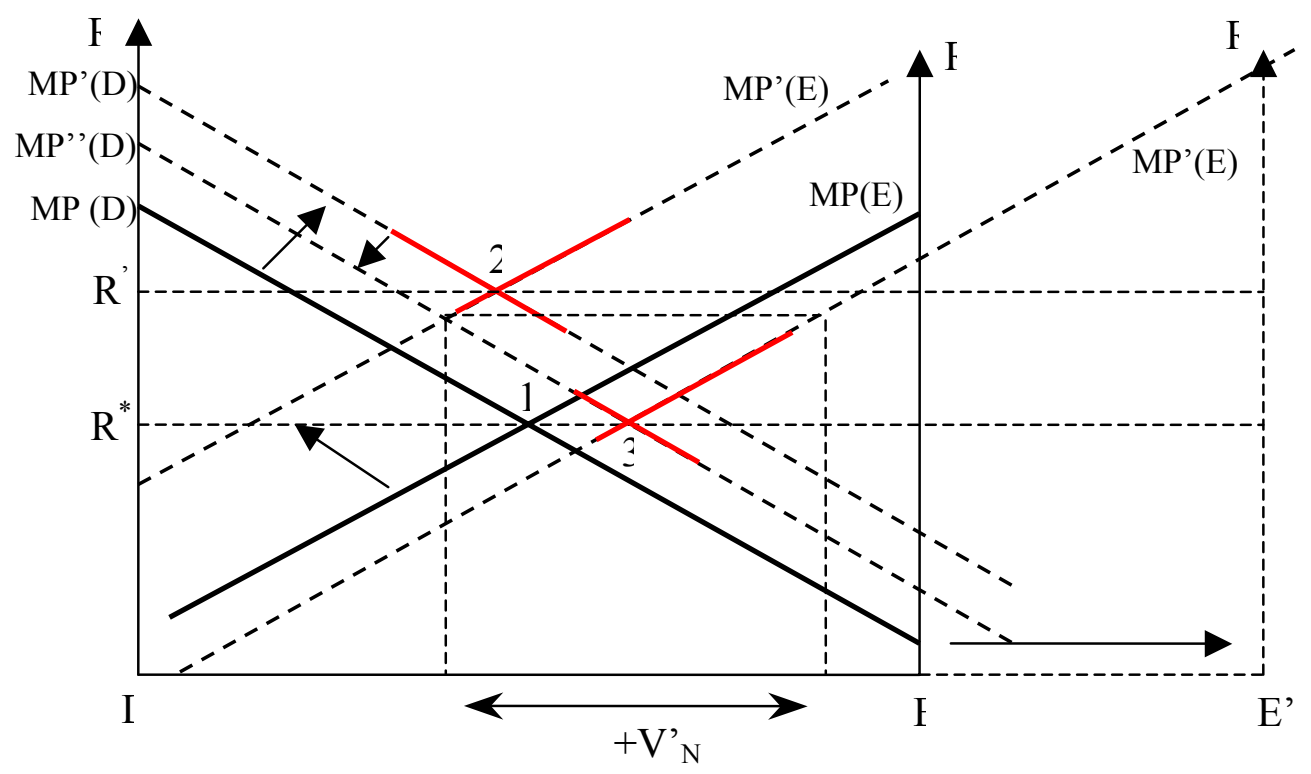

Fig. 2.1. High-skilled immigration induced change in FDI flow (capital inflow decreases the price of domestic non-traded good). 


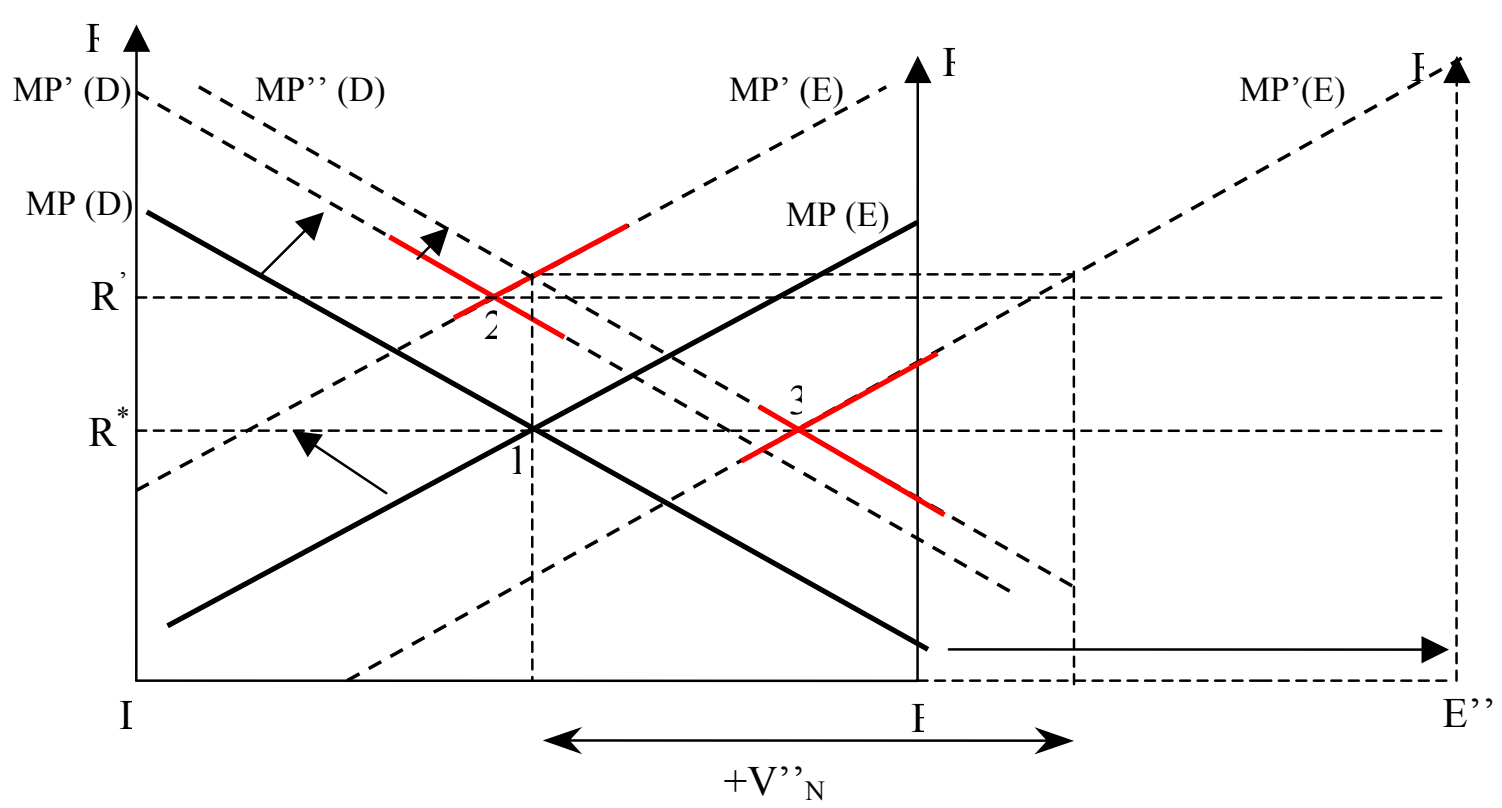

Fig. 2.2. High-skilled immigration induced change in FDI flow (capital inflow increases the price of domestic non-traded good).

If $\alpha_{N}$ is positive, the capital inflow will lead to the fall in non-traded good price (figure 2.1.). The marginal product of capital in D sector schedule shifts downwards, and at the same time the distance between two vertical axes increases. A new equilibrium is achieved at point 3 where capital price gets back to its world equilibrium level $R^{*}$. The resulting FDI inflow corresponds to the distance $V^{\prime}{ }_{N}$.

A negative $\alpha_{N}$ implying the rise in non-traded good price (figure 2.2.), moves both marginal product of capital schedules to the right. Thus, a higher amount of foreign capital is necessary to decrease the capital price to its world level $\left(V^{\prime \prime}{ }_{N}\right)$, compared to $\left(V^{\prime}{ }_{N}\right)$ in the case of negative $\alpha_{N}$.

To conclude, high-skilled immigration always results in inward foreign capital flows; moreover, the FDI inflow will be more (less) important, if the consecutive production possibility frontier shift is biased towards export (non-traded) good.

\subsection{LOW-SKILLED IMMIGRATION.}


The channels by low-skilled immigrants induce FDI flows are similar to those outlined in the high-skilled immigration case. Low-skilled immigrants are specific to the domestic nontraded sector, and the first effect of their inflow is the upward shift in the schedule of marginal product of capital in D sector (from MP(D) to $\mathrm{MP}(\mathrm{E})$ on figures 3.1. and 3.2.), raising the price of capital. At the same time, higher potential for the production of non-traded good decreases its price and moves the marginal product of capital schedule backwards, thus pushing capital price down. The aggregate effect on capital price depends on the value of elasticity of substitution between domestic non-traded and imported good $\sigma$ : the capital price will increase (decrease), if $\sigma$ is higher (lower) than the elasticity of factor substitution in domestic industry $^{12} \sigma_{D}$. Figure 3.1 (3.2.) corresponds to the case where low-skilled immigration leads to lower (higher) capital price, with equilibrium moving from point 1 to 2 . As a consequence, sufficiently low (high) level of $\sigma$ implies outflow of domestic capital (inflow of foreign capital).

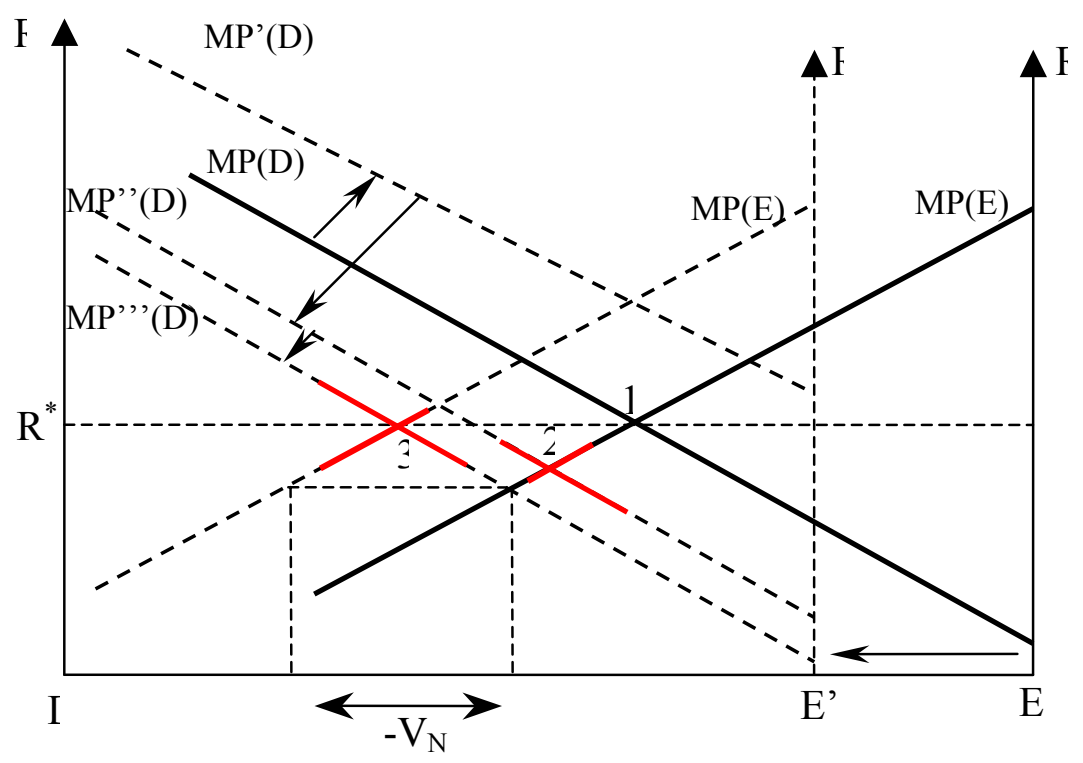

Fig. 3.1. Low-skilled immigration induced change in FDI flow $\left(\sigma<\sigma_{D}\right)$, capital inflow decreases the price of domestic non-traded good.

\footnotetext{
${ }^{12}$ The formal proof can be found in Ivlevs (2005).
} 


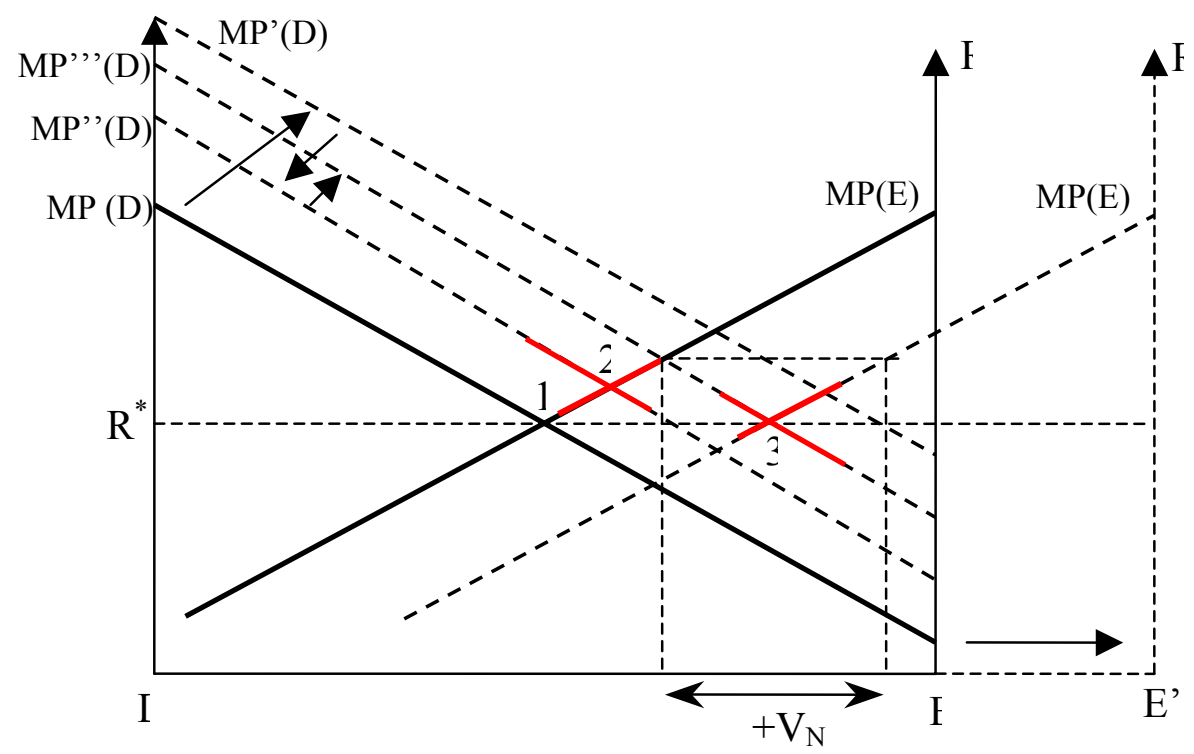

Fig. 3.1. Low-skilled immigration induced change in FDI flow $\left(\sigma>\sigma_{D}\right)$, capital inflow increases the price of domestic non-traded good.

As in the case of high-skilled immigrants, capital flows induce changes in non-traded good price, depending of the values of $\alpha_{N}$ (showing which sector absorbs more capital) and elasticity of substitution between consumption goods $\sigma$. This can increase or decrease capital price, again modifying the extent of FDI inflows or outflows. In figure 3.1. I show the case where capital outflow diminishes non-traded good price (otherwise the curve MP','(D) would end up somewhere between MP(D) and MP' (D)). In figure 3.2. capital inflow increases the domestic non-traded good price.

To obtain the formal expression for the change in capital flows after low-skilled immigration, one proceeds as in the case of high-skilled labour inflow (see equations 16.1. and 16.2.):

$$
\frac{\hat{V}_{N}}{\hat{V}_{D}}=\frac{\left(-\beta_{D} \frac{\alpha_{D}}{(\sigma+\Omega)}+\frac{\lambda_{N D}}{\Delta}\right)}{\left(\beta_{D} \frac{\alpha_{N}}{(\sigma+\Omega)}+\frac{1}{\Delta}\right)}=\frac{\lambda_{N D}\left(\sigma-\sigma_{D}\right)}{\left(\frac{\theta_{N D} \sigma_{D}}{\theta_{D D}}+\sigma\right)}
$$

Equation (17) confirms the critical role of the elasticity of substitution between consumption goods in determining the direction of FDI flows after low-skilled immigration. If non-traded and imported goods are strong substitutes $(\sigma \rightarrow \infty)$, one percent increase in low-skilled 
immigration will lead to $\lambda_{N D}$ capital inflow. If elasticity of substitution between consumption goods is inferior to elasticity of factor substitution in production, the capital will flow out of the country.

\section{ATTITUDES TOWARDS IMMIGRATION}

In this part of the work, I explain the attitudes that native individuals would take towards foreign labour, both low-skilled and high-skilled. After having examined attitudes when capital is mobile across borders (sub-section 5.1), I compare them with the attitudes that are obtained in an identical economy in the absence of international capital mobility (subsection 5.2.). This would provide additional understanding of the potential change in attitudes towards immigration in the globalisation context, particularly if a country liberalises its capital flows.

\subsection{ATTITUDES TOWARDS IMMIGRATION WITH INTERNATIONAL CAPITAL MOBILITY.}

Normally, if immigration of either high-skilled or low-skilled labour leads to positive FDI flows, inducing economy's higher productive capacity and growth prospects, native individuals should advocate such immigration. However, it can be argued that individuals are more preoccupied by immediate changes in their personal income instead of thinking about future average per capita income growth. In other words, "selfish" considerations about personal welfare will (almost) always dominate "altruistic" ones about economy's as a whole growth prospects. Thus, when asked to express their views about inflow of foreign labour and, consequently, on the shape of immigration policy, I assume that the typical voter's choice would be the reflection of the change in her welfare after immigration.

Leaving social, xenophobic or cultural arguments aside ${ }^{13}$, I will assume that individual's welfare is influenced only by changes in her nominal income and consumption prices. In addition, I make a hypothesis that each individual possesses exactly one unit of either highskilled or low-unskilled labour, and a positive amount of capital. All individuals are assumed

\footnotetext{
${ }^{13}$ However, see e.g. Schiff (2002), Mayda (2005) and O’Rourke and Sinnott (2004) for the theoretical and empirical analysis if non-economic factors influencing attitudes towards immigrants.
} 
to have identical utility (welfare) functions. Following Mayer's (1984) approach for calculating median voter utility change after the imposition of a tariff, I obtain the utility change for the inflow of immigrants ${ }^{14}$ :

$\frac{\partial U^{i}}{\partial V_{j}}=\frac{\partial U^{i}}{\partial y^{i}}\left(\frac{\hat{R}_{N}}{\hat{V}_{j}} \frac{R_{N}}{V_{j}} V_{N}^{i}+\frac{\hat{R}_{h}}{\hat{V}_{j}} \frac{R_{h}}{V_{j}} V_{h}^{i}\right), \mathrm{j}=\mathrm{E}, \mathrm{D}, \mathrm{h}=\mathrm{E}, \mathrm{D}$

where $h$ is individual's $i$ association with either type of specific labour.

Taking into account perfect international capital mobility $\left(\hat{R}_{N}=0\right)$ and the fact that each individual owns exactly one unit of labour $\left(V_{h}^{i}\right)$, equation (18.1) transforms into:

$\frac{\partial U^{i}}{\partial V_{j}}=\frac{\partial U^{i}}{\partial y^{i}} \frac{\hat{R}_{h}}{\hat{V}_{j}} \frac{R_{h}}{V_{j}}, \quad \mathrm{j}=\mathrm{E}, \mathrm{D}, \mathrm{h}=\mathrm{E}, \mathrm{D}$

Thus, to know the attitude of a particular individual toward the inflow of low-skilled and high-skilled labour, it is sufficient to establish the direction of change in her labour income after immigration. Since the majority may be represented by high-skilled or low-skilled voters, I need to obtain the signs of $\frac{\hat{R}_{D}}{\hat{V}_{D}}, \frac{\hat{R}_{D}}{\hat{V}_{E}}, \frac{\hat{R}_{E}}{\hat{V}_{D}}, \frac{\hat{R}_{E}}{\hat{V}_{E}}$. According to equations (7) and (8), the wage of either specific labour depends both on changes in factor supplies and changes in domestic price (the price for exported good is assumed to be constant). As the immigration of foreign workers leads to FDI flows, and both labour and capital flows modify domestic nontraded good price, the growth of the price of specific factor can be expressed as follows:

$$
\hat{R}_{h}=f\left\{\hat{p}_{D}\left(\hat{V}_{j}, \hat{V}_{N}\right), \hat{V}_{j}, \hat{V}_{N}\left(\hat{V}_{j}\right)\right\} \quad j=D, E
$$

The analysis in the previous chapter suggests that high-skilled immigrants raise price of the non-traded good, and the low-skilled decrease it. Even if the consecutive capital flows may change the non-traded good price in the opposite direction, the immigration effect will be

\footnotetext{
${ }^{14}$ See Ivlevs (2005), appendix A.7.
} 
dominant ${ }^{15}$. Table 1 displays the sign of the effect that immigration, FDI flows and domestic price exert on specific labour wage.

\begin{tabular}{|c|c|c|c|}
\hline & & $\hat{R}_{D}$ & $\hat{R}_{E}$ \\
\hline High-skilled immigration & $\begin{array}{c}V_{E} \rightarrow V_{N}, p_{D} \\
(\uparrow)\end{array}$ & -++ & -+- \\
\hline $\begin{array}{c}\text { Low-skilled immigration } \\
\sigma>\sigma_{D}\end{array}$ & $\begin{array}{c}V_{D} \rightarrow V_{N}, p_{D} \\
(\uparrow)\end{array}$ & -+- & -++ \\
\hline $\begin{array}{c}\text { Low-skilled immigration } \\
\sigma<\sigma_{D}\end{array}$ & $\begin{array}{c}V_{D} \rightarrow V_{N}, p_{D} \\
(\uparrow)\end{array}$ & --- & \\
\hline$(\downarrow)$ & & -+ \\
\hline
\end{tabular}

Table 1. Specific factor returns and immigration.

The aggregate effect is unambiguous only in the case of $\frac{\hat{R}_{D}}{\hat{V}_{D}}$ (if $\sigma<\sigma_{D}$ ): the wage (or welfare) of the low-skilled individual decreases with the inflow of immigrants of the same type given that domestic non-traded and imported goods are sufficiently weak substitutes. Using equation (5) and keeping in mind that $\hat{p}_{E}=\hat{R}_{N}=0$ in final equilibrium, one can show that $\frac{\hat{R}_{E}}{\hat{V}_{D}}=0$ independently of the level of $\sigma$; in this case, positive effects outweigh negative ones, and welfare of high-skilled voter will not be affected by low-skilled immigration. Remain the cases of $\frac{\hat{R}_{D}}{\hat{V}_{E}}, \frac{\hat{R}_{E}}{\hat{V}_{E}}$ and $\frac{\hat{R}_{D}}{\hat{V}_{D}}$ (if $\sigma>\sigma_{D}$ ), which must be solved for algebraically. For this, I substitute equations (15), (16.2) and (17) into equations (7) and (8). Simplifying ${ }^{16}$ yields a positive value for $\frac{\hat{R}_{D}}{\hat{V}_{E}}$, a negative value for $\frac{\hat{R}_{D}}{\hat{V}_{D}}$ (irrespectively of the value of $\sigma$ ). The sign of $\frac{\hat{R}_{E}}{\hat{V}_{E}}$ depends on the value of $\Delta$. If $\Delta$ is higher (lower) than 1, nominal wage of the skilled workers goes down (up) with the inflow of high-skilled immigrants. This corresponds to the equation (8) where lower levels of $\Delta$ reinforce the positive effect stemming from capital inflow on $R_{E}$. Alternatively, positive effect from capital inflow

\footnotetext{
${ }^{15}$ See app. A.2- A.4 for the formal proof.

${ }^{16}$ See appendix.
} 
outweighs negative effects from higher supply the high-skilled and higher non-traded good price, if $\Delta$ is inferior to 1 .

The changes in factor prices due to immigration are directly transmitted the preferences of native individuals over foreign labour inflow. According to equation (18.2) the voter will be for (against) the inflow of immigrants, if the nominal income of the specific labour that she owns goes up (down). Table 2 summarises the findings about the direction of change of specific factor prices, showing the stance taken by the median voter vis-à-vis low-skilled and high-skilled immigrants.

\begin{tabular}{|c|c|c|c|}
\hline & \multicolumn{2}{|c|}{ Median voter } \\
\hline & & Low-skilled & High-skilled \\
\hline \multirow{4}{*}{ Immigrants } & Low-skilled & Against & Indifferent \\
\hline & \multirow{3}{*}{ High-skilled } & \multirow{3}{*}{ For } & For if $\Delta<1$ \\
\hline & & & Indifferent if $\Delta=1$ \\
\hline & & & Against if $\Delta>1$ \\
\hline
\end{tabular}

Table 2. Natives' attitudes towards immigration.

As mentioned above, the attitudes on immigration are based exclusively on the variation of personal income. Indeed, it is almost impossible to find an individual voting for the removal of migration barriers, if her welfare decreases with immigration. However, a particular case of indifferent stance towards immigrants deserves more attention. The above-mentioned results suggest that the high-skilled median voter would be indifferent to the inflow of low-skilled foreign workers because there is no change in her nominal income. In this case these voters could take into consideration other effects from immigration, both of economic and noneconomic nature ${ }^{17}$ and become pro- or anti-immigrant. For example, the inflow of low-skilled immigrants leads to the change in capital stock of the economy, with the direction of change depending on the level of $\sigma$. More capital means the expansion of production possibilities and higher strong prospects, and vice versa, therefore, I would assume that the natives prefer inward capital flows to the outward ones. Again, I consider only economic effects of capital

\footnotetext{
${ }^{17}$ Compared to the change in nominal income, other economic and non-economic effects from immigration can defined as those of "second order". They become decisive only if the "first order" effect, or change in individual's nominal income" is equal to zero.
} 
flows (new working places, growth etc.), ignoring all non-materialistic arguments, as I did for the case of labour flows ${ }^{18}$. Thus, high-skilled median voter will favour (oppose) low-skilled immigration, if it will bring about foreign capital inflow, that is, if the elasticity of substitution between imported and non-traded good exceeds (falls short of) the elasticity of factor substitution in non-traded good sector.

\subsection{CHANGE IN ATTITUDES TOWARDS IMMIGRATION IF CAPITAL BECOMES MOBILE INTERNATIONALLY.}

The purpose of this subsection is to find out how would change the attitudes towards immigrants if a country becomes integrated into international capital markets. For this, I use the results obtained in Ivlevs (2005) for the economy which is closed in the sense that international capital movements are possible.

Specifically, without international capital mobility, the return to capital is not exogenous and varies if there is immigration. Therefore, native individuals will be concerned by their both labour and capital income. By assumption, each individual owns one unit of sector specific labour (low-skilled or high-skilled) and some amount of capital. Low-skilled (high-skilled) natives are assumed to be capital poor (capital rich) which means that altogether they posses less capital than it is employed in the sector they are specific to. Capital is equally distributed within each labour group. Given such distribution of capital, the attitudes toward immigration are summarised in the following table ${ }^{19}$.

While the low-skilled native voters will always be against the inflow of low-skilled immigrants and the high-skilled will always favour high-skilled immigration, the elasticity of substitution between non-traded and imported goods appears to be crucial in determining natives' attitudes towards labour of different type. Comparing table 3 to the results obtained in table 2 and assuming that voters prefer positive FDI to negative $\mathrm{FDI}^{20}$, natives' attitudes towards low-skilled immigrants should not change when economy liberalises its capital flows. However, the reasons why high-skilled natives prefer of not low-skilled immigrants are not

\footnotetext{
${ }^{18}$ One could easily argue that some natives simply do not like any inflow of foreign capital, even if it contributes to the welfare of the economy.

${ }^{19}$ See Ivlevs (2005), table 3.

${ }^{20}$ This means that "Indifferent" should be replaced by "For if sig $>$ sig D, and Against if sig $<$ D".
} 
the same in both cases. With no international capital mobility, these attitudes are determined directly by changes in factor income. When capital becomes mobile across borders the direct effect from factor income change is zero, but I assume that immigration induced positive (negative) FDI flows make native voters better (worse) off.

\begin{tabular}{|c|c|c|c|}
\hline \multirow{2}{*}{\multicolumn{2}{|c|}{}} & \multicolumn{2}{|c|}{ Median voter } \\
\cline { 3 - 4 } Immigrants & Low-skilled & Low-skilled & High-skilled \\
& & Against & For if sig $>\sigma_{D}$ \\
& & Against if $\sigma<\sigma_{D}$ \\
\cline { 2 - 4 } & \multirow{3}{*}{ High-skilled } & For if sig<sigLS & For \\
\hline
\end{tabular}

Table 3. Attitudes towards immigration without international capital mobility.

As to the attitudes towards high-skilled immigrants, those of thee low-skilled natives improve and become positive irrespectively of the level of sigma. On the other hand, international capital mobility increases high-skilled natives' opposition to high-skilled immigrants if "delta" is higher than 1.

\section{CONCLUSIONS}

Contrary to the rapid trade and capital flows liberalization, international labour flows are often determined by restrictive immigration policies. In such a situation labourers' wages systematically fall short of those in host countries, whereas free international movement of capital tend to assure equalization of capital price across countries. Another reason for asymmetry between labour and capital flows consists in higher physical, human and economic costs of migration. This can explain the speed with which different factors cross borders for better employment opportunities. Relying on these asymmetries, I assume that capital flows respond endogenously to any exogenous migration shock (represented, for example, by the increase in immigration quota), and try to determine whether international high-skilled and low-skilled labour on the one hand and capital flows on the other are complements or substitutes. 
I find that the inflow of high-skilled immigrants always induces an inward flow of FDI, meaning the two are complements. On the other hand, low-skilled immigration may cause an outflow of capital, if domestic non-traded good and imported good are sufficiently weak substitutes in consumption, implying a factor flows are substitutes in quantity sense.

Since the results of the model can be applied to immigration and emigration, some conclusions can be drawn concerning the aggregate welfare in sending countries. The outflow of high-skilled individuals is particularly disastrous for the economy, since it leads to net capital outflow. On the contrary, low-skilled emigration may result in net FDI inflows, if nontraded and imported goods are weak substitutes. Therefore, taking the example of the enlarged EU, governments of the new member states should prevent the outflow of high-skilled workers, in order to avoid capital outflow. 


\section{SELECTED REFERENCES}

Baldwin, R., Venables, A., "International Migration, Capital Mobility and Transitional Dynamics" Economica, Vol.61, No.243, pp 285-300, August 1994.

Benhabib, J., (1996), "On the political economy of immigration", European Economic Review, vol. 40(9), pages 1737-1743

Bilal, S., Grether, J.-M. and de Melo, J., (2003), "Attitudes Towards Immigration: A TradeTheoretic Approach" . Review of International Economics, Vol. 11, pp. 253-267

Blonigen, A., Wilson, W., (1999), "Explaining Armington: What Determines Substitutability Between Home and Foreign Goods?" Canadian Journal of Economics, 32 (1): 1-21

Boeri T., Hanson, G. and McKormick B., (2002), Immigration Policy and the Welfare State, Oxford University Press

Buch, C., Kleinert, J., Toubal, F., (2003), "Where Enterprises Lead, People Follow? Links between Migration and German FDI", Working Papers 1190, Kiel Institute for World Economics.

Clarke, H., Smith, L., (1996), "Labor immigration and capital flows: long-term Australian, Canadian and United States experience". International Migration Review, Vol. 30, No. 4

Davis, D.R., and Weinstein, D. E., (2002),'Technological Superiority and the Losses from Migration", National Bureau of Economic Research, NBER Working Paper 897, Cambridge, Mass.

Facchini, G., and Willmann, G., (2004), “The Political Economy of International Factor Mobility", forthcoming in the Journal of International Economics. 
Faini, R., (2004), Trade liberalization in a globalizing world”, IZA Discussion Paper No 1406, November.

Faini, R., de Melo, J., and Zimmermann, K., eds. (1999), "Trade and Migration: The Issues and the Evidence", Cambridge University Press.

Grether, J.-M., de Melo, J. and Muller, T., (2001), "The Political Economy of International Migration in a Ricardo-Viner Model" in S. Djajic ed. International Migration: Trends, Policy, and Impact, Routledge, London.

Hillman, A., Weiss, A., (1999), "Beyond International Factor Movements: Cultural Preferences, Endogenous Policies and the Migration of People: An Overview”, in Faini et al. Eds.

Ivlevs, A, (2005), “Attitudes Towards Immigration in a Small Open Economy”, Working paper, CEDERS, University of Aix-Marseille II, presented at the conference "Institutions and policies for the new Europe" in Siena, Italy, October 2005

Jones, R., (1971), "A Three-Factor Model in Theory, Trade and History", in Trade, Balance of Payments and Growth, J. Bhagwati et al (eds).

Jones, R., (1975), "Income Distribution and Effective Protection in a Multi-Commodity Trade Model", Journal of Economic Theory, vol. 11, pp 1-15.

López, R., Schiff, M., (1998), "Migration and the Skill Composition of the Labor Force: the Impact of Trade Liberalization in LDCs", Canadian Journal of Economics, vol. 31(2), pages 318-336.

Mayda, A.M., (2005), "Who is against immigration? A cross-country investigation of individual attitudes towards immigrants”, CEPR Discussion Paper No. 5055, Centre for Economic Policy Research, London.

Mayer, W., (1984), “Endogenous tariff formation” American Economic Review, Vol. 74, No. 
De Melo, J., Robinson, S., (1989), "Product Differentiation and the Treatment of Foreign Trade in Computable General Equilibrium Models of Small Economies." Journal of International Economics 27: 47-67

Robinson, S., Thierfelder, K., (2003), “Trade and Tradability: Exports, Imports, and Factor Markets in the Salter-Swan model”, The Economic Record, Vol. 79, No. 244.

O’Rourke, K. H., Sinnott, R., (2004), “The Determinants of Individual Attitudes Towards Immigration", Mimeo, Trinity College Dublin.

Ruffin, R., Jones, R., (1977), "Protection and Real Wages: The Neoclassical Ambiguity”, Journal of Economic Theory, 14, 337-48.

Schiff, M., (2002) "Love Thy Neighbor: Social Capital, Trade and Optimal Migration Policy". European Journal of Political Economy (March).

United Nations (2004), World Economic and Social Survey 2004: International Migration, New York, November

Wong, K. (1986), “Are international trade and factor mobility substitutes?”, Journal of International Economics, 21, pages 25-43.

Wong, K., (1995), “International Trade in Goods and Factor Mobility”, MIT Press, 1995.

Wong, K., (2004), “Are International Capital Mobility and International Labor Migration Substitutes?" presented at Kiel Week Conference "Labour Mobility and the World Economy". 
Appendix.

A.1. To prove that $\beta_{D} \frac{\alpha_{N}}{(\sigma+\Omega)}+\frac{1}{\Delta}$ is positive.

$$
\begin{aligned}
& \beta_{D} \frac{\alpha_{N}}{(\sigma+\Omega)}+\frac{1}{\Delta}=\frac{\beta_{D} \frac{1}{\Delta}\left(\frac{\theta_{N D} \sigma_{D}}{\theta_{D D}}-\frac{\theta_{N E} \sigma_{E}}{\theta_{E E}}\right)}{\left(\sigma+\theta_{N D} \frac{\sigma_{D}}{\theta_{D D}} \beta_{E}+\theta_{N E} \frac{\sigma_{E}}{\theta_{E E}} \beta_{D}\right)}+\frac{1}{\Delta}= \\
& =\frac{1}{\Delta}\left(-\beta_{D} \frac{\left(\theta_{N E} \frac{\sigma_{E}}{\theta_{E E}} \beta_{D}-\theta_{N D} \frac{\sigma_{D}}{\theta_{D D}} \beta_{D}\right)}{\left(\theta_{N E} \frac{\sigma_{E}}{\theta_{E E}} \beta_{D}+\sigma+\theta_{N D} \frac{\sigma_{D}}{\theta_{D D}} \beta_{E}\right)}+1\right)
\end{aligned}
$$

With all parameters positive, the ratio $\frac{\left(\frac{\theta_{N E} \sigma_{E}}{\theta_{E E}} \beta_{D}-\frac{\theta_{N D} \sigma_{D}}{\theta_{D D}} \beta_{D}\right)}{\left(\theta_{N E} \frac{\sigma_{E}}{\theta_{E E}} \beta_{D}+\sigma+\theta_{N D} \frac{\sigma_{D}}{\theta_{D D}} \beta_{E}\right)}$ cannot be superior to 1. Multiplying it by $\beta_{D}$, which by definition is positive and less than one, and subtracting the product from 1 gives some positive value.

A.2. To prove that $\frac{\hat{R}_{D}}{\hat{V}_{E}}$ is positive :

Insert equation (16.2) into (7):

$$
\begin{aligned}
& \hat{R}_{D}=\left[\beta_{D}+\frac{1}{\theta_{D D}} \beta_{E}\right]\left(-\frac{1}{(\sigma+\Omega)}\left(\alpha_{E} \hat{V}_{E}+\alpha_{N} \hat{V}_{N}\right)\right)+\frac{1 \theta_{N D}}{\Delta \theta_{D D}}\left(\hat{V}_{N}-\lambda_{N E} \hat{V}_{E}\right)= \\
& =\hat{V}_{E}\left\{\frac{\left(\beta_{D}+\frac{1}{\theta_{D D}} \beta_{E}\right)}{(\sigma+\Omega)}(-1)(\underbrace{\alpha_{E}+\alpha_{N} \frac{\left(-\beta_{D} \frac{\alpha_{E}}{(\sigma+\Omega)}+\frac{\lambda_{N E}}{\Delta}\right)}{\left(\beta_{D} \frac{\alpha_{N}}{(\sigma+\Omega)}+\frac{1}{\Delta}\right)}}_{(1)})+\frac{1 \theta_{N D}}{\Delta \theta_{D D}}(\underbrace{\left.\frac{\left(-\beta_{D} \frac{\alpha_{E}}{(\sigma+\Omega)}+\frac{\lambda_{N E}}{\Delta}\right)}{\left(\beta_{D} \frac{\alpha_{N}}{(\sigma+\Omega)}+\frac{1}{\Delta}\right)}-\lambda_{N E}\right)}_{(2)})\right\}
\end{aligned}
$$


Evaluate separately expressions (1) and (2):

1)

$$
\alpha_{E}+\alpha_{N} \frac{\left(-\beta_{D} \frac{\alpha_{E}}{(\sigma+\Omega)}+\frac{\lambda_{N E}}{\Delta}\right)}{\left(\beta_{D} \frac{\alpha_{N}}{(\sigma+\Omega)}+\frac{1}{\Delta}\right)}=\frac{\left(\alpha_{E}+\alpha_{N} \lambda_{N E}\right)}{\left(\beta_{D} \frac{\alpha_{N}}{(\sigma+\Omega)}+\frac{1}{\Delta}\right)}
$$

The denominator $\left(\beta_{D} \frac{\alpha_{N}}{(\sigma+\Omega)}+\frac{1}{\Delta}\right)$ is positive (see A.1), collecting terms in nominator yields:

$$
\alpha_{E}+\alpha_{N} \lambda_{N E}=-1-\lambda_{N E} \frac{1}{\Delta}\left(\frac{\theta_{N D} \sigma_{D}}{\theta_{D D}}-\frac{\theta_{N E} \sigma_{E}}{\theta_{E E}}\right)+\lambda_{N E} \frac{1}{\Delta}\left(\frac{\theta_{N D} \sigma_{D}}{\theta_{D D}}-\frac{\theta_{N E} \sigma_{E}}{\theta_{E E}}\right)=-1
$$

Thus, expression (1) is negative.

2)

$$
\frac{\left(-\beta_{D} \frac{\alpha_{E}}{(\sigma+\Omega)}+\frac{\lambda_{N E}}{\Delta}\right)}{\left(\beta_{D} \frac{\alpha_{N}}{(\sigma+\Omega)}+\frac{1}{\Delta}\right)}-\lambda_{N E}=\frac{-\frac{\beta_{D}}{(\sigma+\Omega)}\left(\alpha_{E}+\lambda_{N E} \alpha_{N}\right)}{\left(\beta_{D} \frac{\alpha_{N}}{(\sigma+\Omega)}+\frac{1}{\Delta}\right)}=\frac{\frac{\beta_{D}}{(\sigma+\Omega)}}{\left(\beta_{D} \frac{\alpha_{N}}{(\sigma+\Omega)}+\frac{1}{\Delta}\right)}>0
$$

$\rightarrow$ the coefficient of $\hat{V}_{E}$ in the initial equation is positive $\rightarrow \frac{\hat{R}_{D}}{\hat{V}_{E}}>0$.

A.3. to prove that $\frac{\hat{R}_{D}}{\hat{V}_{D}}$ is negative :

Insert equation (17) into (7): 


$$
\begin{aligned}
& \hat{R}_{D}=\left[\beta_{D}+\frac{1}{\theta_{D D}} \beta_{E}\right]\left(-\frac{1}{(\sigma+\Omega)}\left(\alpha_{D} \hat{V}_{D}+\alpha_{N} \hat{V}_{N}\right)\right)+\frac{1 \theta_{N D}}{\Delta \theta_{D D}}\left(\hat{V}_{N}-\lambda_{N D} \hat{V}_{D}\right)= \\
& =\hat{V}_{D}\left\{\frac{\left(\beta_{D}+\frac{1}{\theta_{D D}} \beta_{E}\right)}{(\sigma+\Omega)}(-1)(\underbrace{\left.\alpha_{D}+\alpha_{N} \frac{\left(-\beta_{D} \frac{\alpha_{D}}{(\sigma+\Omega)}+\frac{\lambda_{N D}}{\Delta}\right)}{\left(\beta_{D} \frac{\alpha_{N}}{(\sigma+\Omega)}+\frac{1}{\Delta}\right)}\right)+\frac{1 \theta_{N D}}{\Delta \theta_{D D}}}_{(1)})\right. \\
& (\underbrace{\left.\frac{\left(-\beta_{D} \frac{\alpha_{D}}{(\sigma+\Omega)}+\frac{\lambda_{N D}}{\Delta}\right)}{\left(\beta_{D} \frac{\alpha_{N}}{(\sigma+\Omega)}+\frac{1}{\Delta}\right)}-\lambda_{N D}\right)}_{(2)})
\end{aligned}
$$

It is easy to prove that expression (1) is positive and (2) is negative (see app. A.2. for similar calculus). Therefore, $\frac{\hat{R}_{D}}{\hat{V}_{D}}$ is necessarily negative.

A.4. to obtain the sign of $\frac{\hat{R}_{E}}{\hat{V}_{E}}$

Insert equation (16.2) into (7) and simplify :

$$
\begin{aligned}
& \hat{R}_{E}=-\frac{\theta_{N E}}{\theta_{E E}} \beta_{D}\left(-\frac{1}{(\sigma+\Omega)}\left(\alpha_{E} \hat{V}_{E}+\alpha_{N} \hat{V}_{N}\right)\right)+\frac{1 \theta_{N E}}{\Delta \theta_{E E}}\left(\hat{V}_{N}-\lambda_{N E} \hat{V}_{E}\right)= \\
& =\hat{V}_{E} \frac{\theta_{N E}}{\theta_{E E}}\left[\frac{\beta_{D}}{(\sigma+\Omega)}\left(\alpha_{E}+\alpha_{N} \frac{\left(-\beta_{D} \frac{\alpha_{E}}{(\sigma+\Omega)}+\frac{\lambda_{N E}}{\Delta}\right)}{\left(\beta_{D} \frac{\alpha_{N}}{(\sigma+\Omega)}+\frac{1}{\Delta}\right)}\right)+\frac{1}{\Delta}\left(\frac{\left(-\beta_{D} \frac{\alpha_{E}}{(\sigma+\Omega)}+\frac{\lambda_{N E}}{\Delta}\right)}{\left(\beta_{D} \frac{\alpha_{N}}{(\sigma+\Omega)}+\frac{1}{\Delta}\right)} \lambda_{N E}\right)\right]= \\
& =\hat{V}_{E} \frac{\theta_{N E}}{\theta_{E E}}\left[\frac{\frac{1}{\Delta} \beta_{D}(1-\Delta)}{(\sigma+\Omega)\left(\beta_{D} \frac{\alpha_{N}}{(\sigma+\Omega)}+\frac{1}{\Delta}\right)}\right]
\end{aligned}
$$

